\title{
Hypoxia-Inducible Factor 1-Alpha
}

National Cancer Institute

\section{Source}

National Cancer Institute. Hypoxia-Inducible Factor 1-Alpha. NCI Thesaurus. Code C20214.

Hypoxia-inducible factor 1-alpha ( $826 \mathrm{aa}, \sim 93 \mathrm{kDa}$ ) is encoded by the human HIF1A gene. This protein plays a role in transcriptional regulation in response to hypoxia. 